\title{
PENERAPAN METODE PEMBELAJARAN KOOPERATIF DENGAN BANTUAN TUTOR SEBAYA UNTUK MENINGKATKAN MOTIVASI BELAJAR AKUNTANSI
}

\section{IMPLEMENTATION OF COOPERATIVE LEARNING METHOD WITH PEER TUTORING ASSISTANCE TO INCREASE ACCOUNTING LEARNING MOTIVATION}

\author{
Oleh: \\ Evita Rahayu \\ Pendidikan Akuntansi Universitas Negeri Yogyakarta \\ vitha.rahayu23@gmail.com
}

Sukanti, M.Pd.

Staf Pengajar Jurusan P. Akuntansi Universitas Negeri Yogyakarta

\begin{abstract}
Abstrak
Penelitian ini adalah Penelitian Tindakan Kelas (Classroom Action Research) yang bertujuan untuk meningkatkan Motivasi Belajar pada Kompetensi Dasar Membuat Jurnal Penyesuaian Siswa Kelas X Akuntansi 1 SMK Negeri 7 Yogyakarta Tahun Ajaran 2013/2014 dengan menerapkan Metode Pembelajaran Kooperatif dengan Bantuan Tutor Sebaya. Penelitian ini dilaksanakan secara kolaboratif selama dua siklus. Pengumpulan data dalam penelitian ini dengan observasi dan angket. Analisis data yang digunakan untuk mengetahui peningkatan Motivasi Belajar Akuntansi siswa adalah secara deskriptif kuantitatif. Berdasarkan hasil penelitian disimpulkan bahwa Penerapan Metode Pembelajaran Kooperatif dengan Bantuan Tutor Sebaya dapat meningkatkan Motivasi Belajar pada Kompetensi Dasar Membuat Jurnal Penyesuaian Siswa Kelas X Akuntansi 1 SMK Negeri 7 Yogyakarta Tahun Ajaran 2013/2014 yang dibuktikan dengan adanya peningkatan persentase skor Motivasi Belajar Akuntansi sebesar 11,28\% atau diperoleh skor sebesar 74,03\% pada siklus I dan meningkat menjadi 85,31\% pada siklus II. Selain itu berdasarkan angket yang didistibusikan kepada siswa dapat disimpulkan bahwa terjadi peningkatan skor Motivasi Belajar Akuntansi siswa sebesar 4,09\% dari skor siklus I $71,51 \%$ ke siklus II sebesar 75,60\%.
\end{abstract}

Kata kunci: Pembelajaran Kooperatif, Tutor Sebaya, Motivasi Belajar Akuntansi

\begin{abstract}
This research is Classroom Action Research which aims to improve the Learning Motivation on the basic competencies to make Adjusting Entries class X Akuntansi 1 SMK Negeri 7 Yogyakarta academic year 2013/2014 through the Implementation of Cooperative Learning Method with Peer Tutoring Assistance. This research was conducted in two cycles of collaborative form. The technique of collecting data in this research was conducted by observation and questionnaire. This research also applied descriptive approach in analyzing the data. Based on the result of the research, it can be concluded that the Implementation of Cooperative Learning Methods with Peer tutoring Assistance can increase the Learning Motivation on the basic competencies to make Adjusting Entries class X Akuntansi 1 SMK Negeri 7 Yogyakarta academic year 2013/2014 as evidenced by an increasing in the percentage of scores Accounting
\end{abstract}


Learning Motivation for 11, $28 \%$ or obtained a score of $74.03 \%$ in the first cycle and increased to $85.31 \%$ in the second cycle according to the observation. Also based on a questionnaire which is distributed to students can be concluded that there is an increasing in accounting learning motivation scores $4.09 \%$ or increasing from the first cycle $71.51 \%$ to $75.60 \%$ in the second cycle .

Keyword: Cooperative Learning, Peer Tutoring, Accounting Learning Motivation

\section{A. PENDAhuluan}

Bidang pendidikan merupakan salah satu bidang yang sangat penting dan memerlukan perhatian khusus dari semua lapisan masyarakat, bukan hanya pemerintah yang bertanggung jawab atas keberhasilan dan kemajuan pendidikan di Indonesia akan tetapi semua pihak baik guru, orang tua, maupun siswa sendiri ikut bertanggung jawab. Pendidikan nasional berfungsi untuk mengembangkan kemampuan serta meningkatkan mutu kehidupan dan martabat manusia Indonesia dalam rangka upaya meningkatkan tujuan nasional. Pendidikan nasional bertujuan mencerdaskan anak bangsa dan mengembangkan manusia Indonesia seutuhnya, yaitu manusia yang beriman dan bertaqwa terhadap Tuhan Yang Maha Esa dan berbudi pekerti luhur memiliki pengetahuan dan keterampilan, kesehatan jasmani dan rohani kepribadian yang mantap dan mandiri serta rasa tanggung jawab kemasyarakatan dan kebangsaan.

Secara teknis, pendidikan dapat diwujudkan dalam proses belajar mengajar yang menimbulkan interaksi diantara dua unsur yaitu siswa dan guru. Siswa sebagai pihak yang belajar kemudian guru adalah pihak yang mengajar, dengan siswa sebagai subjek pokok dalam belajar. "Mengajar dalam konteks standar proses pendidikan tidak hanya sekedar menyampaikan materi pelajaran, akan tetapi juga dimaknai sebagai proses mengatur lingkungan supaya siswa belajar" (Wina Sanjaya, 2011: 103). Hal ini mengisyaratkan bahwa dalam proses belajar mengajar siswa harus dijadikan sebagai pusat dari kegiatan.

Menurut Muhibbin Syah (2010: 129-136) secara global, faktor-faktor yang mempengaruhi belajar siswa dapat kita bedakan menjadi 3 macam, yakni faktor internal, eksternal, dan pendekatan belajar. Faktor internal meliputi (1) aspek psikologis, misalnya tingkat kecerdasan, sikap, bakat, motivasi, minat dan (2) aspek fisiologis yang meliputi kondisi fisik, kesehatan jasmani dan kondisi panca indera. Faktor eksternal meliputi lingkungan sosial dan non sosial. Faktor pendekatan belajar terdiri dari 3 bentuk dasar yaitu pendekatan tinggi, pendekatan sedang dan pendekatan rendah.

Motivasi sebagai salah satu faktor psikologis dalam proses belajar mengajar memiliki makna sebagai keseluruhan daya penggerak di dalam diri siswa yang menimbulkan kegiatan belajar dan memberikan arah pada kegiatan belajar, sehingga tujuan yang dikehendaki oleh subjek belajar itu dapat tercapai. Motivasi dipandang sebagai dorongan mental yang menggerakkan dan mengarahkan 
perilaku manusia, termasuk perilaku belajar. Di dalam kegiatan belajar mengajar peranan motivasi sangat diperlukan. Dalam hal ini sudah barang tentu peran guru sangat penting. Bagaimana guru melakukan usaha-usaha untuk dapat menumbuhkan dan memberikan motivasi agar anak didiknya melakukan aktivitas belajar dengan baik.

Menurut Sardiman A.M. (2011: 92-95) ada beberapa bentuk dan cara untuk menumbuhkan motivasi dalam kegiatan belajar mengajar di sekolah yaitu dengan memberi angka, memberi hadiah, adanya saingan/kompetisi, menumbuhkan egoinvolvement, memberikan ulangan, mengetahui hasil, memberi pujian, memberi hukuman, meningkatkan hasrat untuk belajar, membangkitkan minat, menentukan tujuan yang diakui dan diterima bagi siswa. Untuk dapat membuat siswa memiliki motivasi belajar penting bagi seorang guru untuk menentukan metode pembelajaran yang tepat. Pembelajaran yang baik adalah bagaimana membuat siswa berpikir mengapa teori tersebut harus dipelajari, bukan menyuruh siswa untuk menghafalkan materi semata (Sardiman, 2011: 40). Pembelajaran yang mampu membuat siswa termotivasi adalah pembelajaran yang menarik, bermakna, dan memberi tantangan.

Berdasarkan observasi awal yang dilakukan tanggal 28 Agustus 2013 di kelas X Akuntansi I SMK Negeri 7 Yogyakarta pada Kompetensi Dasar Mengerjakan Persamaan Dasar Akuntansi, guru mata pelajaran akuntansi masih menggunakan metode ceramah dan latihan soal ketika mengajar sehingga menyebabkan siswa cenderung pasif dan kurang bersemangat. Hal tersebut terlihat antara lain siswa tidak memiliki keuletan dan ketekunan dalam mengerjakan tugas yang diberikan oleh guru. Terdapat 10 siswa dari 32 atau sekitar $31,25 \%$ siswa yang tekun dalam mengerjakan tugas yang diberikan, sisanya yaitu 22 orang atau $68,75 \%$ siswa tidak segera mengerjakan tugas yang diberikan dan bahkan ada siswa yang menunggu pekerjaan siswa yang lain dan mencontek. Jika diberi soal baru, mereka sudah mengeluh dan mengerjakan sebisa mereka, hanya beberapa yang benar-benar mengerjakan soal tersebut dengan serius.

Penggunaan metode pembelajaran konvensional yang digunakan guru juga menimbulkan kejenuhan bagi siswa, terlebih lagi pembelajaran akuntansi di kelas X Akuntansi 1 dilakukan pada jam-jam pelajaran terakhir sehingga siswa menjadi kurang fokus. Siswa lebih senang berbicara dengan teman sebangku diluar materi ketika mengikuti kegiatan pembelajaran, bahkan ditemukan beberapa siswa sibuk bermain telepon genggam dan tidak memperhatikan penjelasan guru serta beberapa siswa mengeluh pelajaran akuntansi sulit untuk dipahami. Ketika guru bertanya apakah ada yang belum jelas, sebagian besar siswa hanya diam dan beberapa saja yang menjawab dengan pelan. Siswa lebih senang bertanya kepada teman sebangku, teman di bangku depan atau di belakang tentang materi yang 
belum dimengerti daripada bertanya kepada guru, karena siswa merasa takut, sungkan dan malu jika akan bertanya kepada guru.

Berdasarkan hasil observasi dan dari beberapa temuan di atas dapat dikatakan bahwa motivasi belajar akuntansi siswa belum optimal. Hal tersebut menyebabkan pembelajaran Akuntansi yang dilakukan kurang menarik bagi siswa, dan belum sepenuhnya dapat menggugah motivasi belajar siswa. Oleh karena itu perlu dicari pemecahannya. Kualitas pembelajaran perlu ditingkatkan salah satunya dengan menggunakan metode pembelajaran yang dapat meningkatkan motivasi belajar siswa.

Metode pembelajaran yang berorientasi pada peningkatan motivasi dan aktivitas siswa saat ini telah banyak dikemukakan. Salah satunya adalah metode pembelajaran kooperatif, dimana siswa akan bekerjasama dalam kelompok, sehingga kemampuan kerjasama akan diasah. Menurut Agus Suprijono (2012: 5458), metode pembelajaran kooperatif melibatkan interaksi diantara siswa dimana dalam proses pembelajaran senantiasa didasarkan atas kerjasama tim, masingmasing individu mempunyai tanggung jawab dalam mencapai tujuan kelompok. Setiap anggota dalam kelompok memiliki saling ketergantungan positif, sehingga memicu setiap anggota untuk selalu berperan aktif dalam kelompoknya. Pembelajaran kooperatif adalah pembelajaran yang dilakukan dengan membentuk kelompok-kelompok kecil yang terdiri dari 4-6 siswa yang heterogen. Menurut Oemar Hamalik (2004: 188-190) teknik yang dapat dikembangkan dengan kelompok kecil antara lain tutorial individual, tutorial kelompok, seminar, lokakarya, teknik klinis, dan diskuisi kelompok terbuka.

Dengan memperhatikan hal tersebut diatas, maka peneliti tertarik untuk menerapkan Metode Pembelajaran Kooperatif dengan teknik tutorial, yaitu dengan pembelajaran yang dilakukan siswa dengan mengajar siswa yang lain. Teknik tutorial dapat dibedakan dalam dua macam yaitu tutor kakak dan tutor sebaya. Tutor kakak adalah pembelajaran yang dilakukan oleh siswa yang lebih tua (kakak kelas) kepada siswa dibawahnya (adik kelas), sedangkan tutor sebaya adalah pembelajaran yang dilakukan oleh siswa dalam kelas yang memiliki kemampuan di atas rata-rata untuk membantu kesulitan siswa lain dalam memahami materi ajar. Pembelajaran Kooperatif dengan Bantuan Tutor Sebaya diharapkan mampu membuat siswa termotivasi dalam mengikuti kegiatan pembelajaran.

Pembelajaran Kooperatif dengan Bantuan Tutor Sebaya akan dilakukan peneliti dalam pembelajaran Akuntansi pada Kompetensi Dasar Membuat Jurnal Penyesuaian. Kompetensi dasar tersebut dipilih berdasarkan pengalamanpengalaman sebelumnya yang dirasakan guru, bahwa membuat jurnal penyesuaian adalah materi yang memerlukan pemikiran logis dan matematis yang terkadang membuat peserta didik kesulitan untuk memahami. Selain itu, metode Pembelajaran Kooperatif dengan Bantuan Tutor Sebaya dipilih karena 
pembelajaran yang biasa digunakan guru pada umumnya adalah diskusi kelas biasa yang kadang menimbulkan persaingan di dalam kelas yang dapat berdampak negatif, untuk itu dengan metode ini diharapkan siswa dapat mengungkapan pendapatnya dalam kelompok, siswa lebih mudah menerima pembelajaran, karena dibantu langsung oleh teman sebayanya dan siswa lebih terdorong untuk dapat mencapai tujuannya dan kegiatan diskusi yang dilakukan dapat menuju pada hal yang positif.

Pembelajaran Kooperatif dengan Bantuan Tutor Sebaya dilakukan atas dasar bahwa ada sekelompok siswa yang lebih mudah bertanya, lebih terbuka dengan teman sendiri dibandingkan dengan gurunya. Pembelajaran yang dilakukan siswa didasari oleh motivasi yang positif dari internal dan eksternal siswa baik yang prestasinya tinggi (si tutor) maupun siswa yang yang prestasinya rendah (si mentor) demi terciptanya suatu kondisi yang tepat bagi siswa untuk secara maksimal menerima bahan ajaran, sehingga tugas yang diberikan seorang guru tidak dianggap sebagai suatu keterpaksaan/beban oleh siswa melainkan sebagai suatu kebutuhan yang harus dipenuhi.

Berdasarkan uraian yang dijelaskan di atas peneliti bermaksud untuk melakukan penelitian dengan judul "Penerapan Metode Pembelajaran Kooperatif dengan Bantuan Tutor Sebaya untuk Meningkatkan Motivasi Belajar pada Kompetensi Dasar Membuat Jurnal Penyesuaian Siswa Kelas X Akuntansi 1 SMK Negeri 7 Yogyakarta Tahun Ajaran 2013/2014”.

\section{B. METODE PENELITIAN}

\section{Desain Penelitian}

Jenis penelitian ini adalah Penelitian Tindakan Kelas (Classroom Action Research). Suharsimi Arikunto (2012: 3) menyebutkan "Penelitian tindakan kelas adalah suatu pencermatan terhadap kegiatan yang sengaja dimunculkan, dan terjadi dalam sebuah kelas". Prosedur yang digunakan adalah proses penelitian tindakan model Kemmis dan Taggart, dengan melakukan 2 siklus.Penelitian ini dilaksanakan melalui bentuk kolaboratif antara peneliti dan guru mata pelajaran Akuntansi.

\section{Waktu dan Tempat Penelitian}

Penelitian dilakukan di Kelas X Akuntansi 1 SMK Negeri 7 Yogyakarta yang beralamat di Jalan Gowongan Kidul JT. III/ 416 Yogyakarta. Penelitian dilakukan meliputi tahap persiapan pada bulan September-Oktober 2013.Tahap pelaksanaan sampai tahap pelaporan yaitu pada bulan November-Desember 2013. 


\section{Subjek dan Objek Penelitian}

Subjek penelitian ini adalah seluruh siswa kelas X Akuntansi 1 SMK Negeri 7 Yogyakarta tahun ajaran 2013/2014 yang berjumlah 32 siswa, sedangkan objek penelitian ini adalah Penerapan Metode Pembelajaran Kooperatif dengan Bantuan Tutor sebaya sebagai upaya meningkatkan Motivasi Belajar pada Kompetensi Dasar Membuat Jurnal Penyesuaian siswa kelas X Akuntansi 1 SMK Negeri 7 Yogyakarta Tahun Ajaran 2013/2014

\section{Prosedur Penelitian}

Penelitian ini akan dilakukan melalui kerjasama dengan guru mata pelajaran akuntansi kelas X Akuntansi 1 SMK Negeri 7 Yogyakarta. Penelitian ini akan dilaksanakan sebanyak dua siklus, dimana masing-masing siklus terdiri dari beberapa komponen, yaitu perencanaan, pelaksanaan, pengamatan dan refleksi. Adapun prosedur pelaksanaannya adalah sebagai berikut:

\section{Siklus I}

a. Perencanaan tindakan (Planning)

1) Menyusun Rencana Pelaksanaan Pembelajaran (RPP) yang digunakan sebagai skenario pembelajaran akuntansi dengan Metode Pembelajaran Kooperatif dengan Bantuan Tutor Sebaya pada Kompetensi Dasar Membuat Jurnal Penyesuaian.

2) Membuat bahan ajar yang digunakan saat pelaksanaan proses pembelajaran dengan kompetensi dasar membuat jurnal penyesuaian.

3) Membuat soal diskusi dan soal latihan jurnal penyesuaian yang digunakan siswa dalam kegiatan diskusi kelompok.

4) Membuat soal tes awal dan soal tes akhir yang digunakan untuk mengukur kemampuan siswa sebelum dan setelah diterapkannya metode pembelajaran kooperatif dengan bantuan tutor sebaya.

5) Memilih siswa yang akan dijadikan tutor sebaya berdasarkan nilai Ujian Tengah Semester (UTS) dan hasil diskusi dengan guru mata pelajaran akuntansi serta menentukan pembagian kelompok-kelompok siswa secara heterogen.

6) Melakukan bimbingan kepada para tutor sebelum pelaksanaan kegiatan pembelajaran dan menjelaskan tugas dan tanggungjawabnya.

7) Membuat lembar observasi yang digunakan untuk mencatat motivasi belajar yang dimunculkan siswa ketika proses pembelajaran.

8) Membuat format catatan lapangan yang digunakan untuk mencatat kejadian-kejadian saat proses pembelajaran berlangsung.

9) Membuat angket yang digunakan untuk mengetahui motivasi belajar akuntansi siswa.

10) Berkonsultasi dengan guru mata pelajaran akuntansi mengenai hal-hal yang berkaitan dengan pelaksanaan proses pembelajaran yang hendak dilaksanakan. 
b. Pelaksanaan Tindakan (Acting)

Apabila tahap perencanaan tindakan telah matang, maka langkah selanjutnya yaitu melaksanakan rencana tersebut di kelas dengan berpedoman pada Rencana Pelaksanaan Pembelajaran yang telah disusun sebelumnya. Pada tahap ini guru sebagai tenaga pengajar melaksanakan tindakan berdasarkan RPP yang telah disusun, sedangkan peneliti melakukan penelitian terhadap segala kegiatan yang dilakukan siswa selama proses pembelajaran dengan menggunakan Metode Pembelajaran Kooperatif dengan Bantuan Tutor Sebaya. Pelaksanaan ini bersifat fleksibel atau berubah-ubah sesuai dengan situasi dan kondisi yang terjadi di lapangan.

c. Pengamatan (Observing)

Kegiatan observasi dilakukan bersamaan dengan pelaksanaan tindakan. Peneliti melakukan pengamatan terhadap kegiatan pembelajaran dengan menerapkan Metode Pembelajaran Kooperatif dengan Bantuan Tutor Sebaya dengan menggunakan lembar observasi dan mencatat proses pembelajaran yang berlangsung dalam catatan lapangan. Dalam melakukan pengamatan peneliti dibantu oleh seorang observer, Pada tahap ini peneliti juga membagikan angket motivasi belajar akuntansi kepada siswa.

d. Refleksi (Reflecting)

Pada tahap ini dimaksudkan untuk mengkaji secara menyeluruh tindakan yang telah dilakukan pada siklus I berdasarkan catatan lapangan dan lembar observasi. Pada saat refleksi observer melakukan diskusi bersama guru mata pelajaran akuntansi. Dari catatan lapangan dilakukan evaluasi terhadap pelaksanaan proses pembelajaran, kemudian diidentifikasi permasalahan yang muncul serta kekurangan dalam penerapan metode selama proses pembelajaran, dan selanjutnya disusun pemecahan atas masalah-masalah yang muncul dengan melakukan perbaikan pada siklus II.

\section{Siklus II}

\section{a. Perencanaan Tindakan (Planning)}

Perencanaan pada siklus II pada dasarnya adalah untuk memperbaiki proses pembelajaran berdasarkan hasil refleksi yang dilakukan pada siklus I. Perencanaan pada siklus II tidak berbeda dengan siklus I yang meliputi kegiatan menyusun Rencana Pelaksanaan Pembelajaran (RPP) dan merancang materi pembelajaran, membuat soal tes awal dan akhir, mengganti siswa yang menjadi tutor, membimbing tutor, dan membuat soal jurnal penyesuaian untuk diskusi dan tugas pekerjaan rumah.

b. Pelaksanaan Tindakan (Acting)

Pelaksanaan tindakan pada siklus II pada dasarnya sama dengan siklus I, hanya saja materi yang disampaikan melanjutkan materi dari yang 
sebelumnya. Materi yang disampaikan pada siklus ini adalah Mencatat Jurnal Penyesuaian, Rekapitulasi jurnal Penyesuaian dan Pembuatan Jurnal Koreksi.

c. Pengamatan (Observing)

Pengamatan dilakukan selama proses pembelajaran sama seperti pada siklus I. Pengamatan dilakukan oleh 2 observer yaitu peneliti dan teman peneliti dengan menggunakan lembar observasi dan catatan lapangan serta pembagian angket motivasi belajar akuntansi siswa.

d. Refleksi (Reflecting)

Tahap refleksi dimaksudkan untuk mengkaji secara menyeluruh tindakan yang telah dilakukan berdasarkan data yang telah terkumpul baik dari siklus I maupun siklus II. Refleksi pada siklus II dilakukan setelah pembelajaran dilakukan. Refleksi siklus II digunakan untuk mengetahui apakah skor rata-rata Motivasi Belajar Akuntansi dari siklus I ke siklus II sudah mengalami peningkatan dan mencapai kriteria minimal. Skor diketahui melalui analisis data berdasarkan hasil observasi dan angket. Penelitian tindakan ini dihentikan pada siklus II karena skor rata-rata motivasi belajar sudah mencapai kriteria minimal.

\section{Teknik Pengumpulan Data}

\section{Observasi}

Obervasi merupakan teknik mengumpulkan data dengan cara mengamati setiap kejadian yang sedang berlangsung dan mencatatnya dengan alat observasi tentang hal-hal yang diteliti. Observasi yang dilakukan merupakan jenis observasi partisipatif. Observasi partisipatif berarti bahwa pengamat harus melibatkan diri atau ikut serta dalam kegiatan yang dilaksanakan oleh individu atau kelompok yang diamati (Nana Sudjana, 2012: 85).

Observasi yang dilakukan bertujuan untuk mengumpulkan data Motivasi Belajar siswa pada Kompetensi Dasar Membuat Jurnal Penyesuaian yang dimunculkan siswa dalam bentuk aktivitas yang dapat diamati pada saat pelaksanaan pembelajaran dengan Metode Pembelajaran Kooperatif dengan Bantuan Tutor Sebaya berlangsung.

\section{Angket}

Dalam penelitian ini, angket digunakan untuk mendapatkan data Motivasi Belajar siswa kelas X Akuntansi 1 SMK Negeri 7 Yogyakarta setelah penerapan Metode Pembelajaran Kooperatif dengan Bantuan Tutor Sebaya langsung dari responden atau siswa. Angket yang digunakan adalah angket tertutup dengan 4 alternatif jawaban. "Angket atau Kuesioner adalah sejumlah pertanyaan/pernyataan tertulis yang digunakan untuk memperoleh informasi dari responden dalam arti laporan tentang diri pribadinya atau hal-hal yang ia ketahui" (Suharsimi Arikunto, 2010: 194). 


\section{Catatan Lapangan}

Catatan lapangan digunakan untuk mendeskripsikan situasi dan kondisi saat pembelajaran di kelas berlangsung. Catatan lapangan ini digunakan untuk mengumpulkan data tentang situasi dan kondisi saat proses pelaksanaan tindakan kelas seperti proses kegiatan belajar mengajar, interaksi guru dengan siswa dan interaksi siswa dengan siswa yang lain.

\section{Dokumentasi}

Dokumentasi dalam penelitian ini adalah daftar nilai yang dimiliki guru yang digunakan sebagai dasar pembentukan kelompok dan pemilihan tutor dalam penerapan Metode Pembelajaran Kooperatif dengan Bantuan Tutor Sebaya.

\section{Instrumen Penelitian}

\section{Pedoman Observasi}

Observasi yang dilakukan membutuhkan adanya pedoman tertulis yang memuat indikator-indikator yang akan diamati. Indikator-indikator yang akan diamati yaitu tekun menghadapi tugas, ulet menghadapi kesulitan, memiliki minat terhadap pelajaran, lebih senang bekerja mandiri, cepat bosan pada tugas-tugas rutin, dapat mempertahankan pendapat, tidak mudah melepaskan hal yang diyakini dan senang mencari dan memecahkan masalah soal-soal. Untuk mendapatkan data yang diinginkan, peneliti membatasi penyusunan Pedoman Observasi hanya terkait dengan Motivasi Belajar Akuntansi siswa yang dapat diamati pada saat pembelajaran Akuntansi berlangsung.

\section{Angket}

Angket digunakan untuk mengumpulkan data tentang Motivasi Belajar Akuntansi siswa. Angket yang digunakan adalah angket tertutup dengan 4 alternatif jawaban. Dalam menyusun angket telah ditetapkan kisi-kisi yang akan dijadikan dasar dalam menyusun pernyataan dalam angket.

\section{Catatan Lapangan}

Catatan lapangan berupa formulir yang digunakan sebagai pencatat berita acara pelaksanaan Pembelajaran Kooperatif dengan Bantuan Tutor Sebaya. Catatan lapangan digunakan untuk menuliskan berbagai kejadian yang berhubungan penelitian yang terjadi di dalam kelas. Catatan lapangan juga digunakan untuk membantu dalam proses refleksi.

\section{Dokumentasi}

Dokumentasi digunakan sebagai penguat data yang diperoleh selama penelitian dilakukan. Dokumen-dokumen yang digunakan berupa daftar nilai siswa dan daftar kelompok. 


\section{Teknik Analisis Data}

Teknik analisis yang digunakan dalam penelitian ini adalah teknik analisis data deskriptif kuantitatif dengan persentase. Data yang diperoleh selanjutnya akan dianalisis untuk mengetahui persentase skor motivasi belajar akuntansi siswa (Sugiyono, 2009: 144). Dari hasil persentase akan dihitung peningkatan yang terjadi terkait motivasi belajar akuntansi. Langkah-langkah yang dilakukan dalam teknik analisis deskriptif adalah sebagai berikut:

1. Skor Motivasi Siswa

a. Menentukan kriteria pemberian skor terhadap masing-masing indikator pada setiap aspek motivasi belajar siswa yang diamati.

b. Menjumlahkan skor untuk masing-masing aspek motivasi belajar yang diamati

c. Menghitung skor motivasi belajar pada setiap aspek yang diamati dengan rumus:

$$
\%=\frac{\text { Skor hasil motivasi belajar siswa }}{\text { Skor Maksimal }} 100 \%
$$

2. Penyajian Data

Setelah data Motivasi Belajar Akuntansi diolah, data ditampilkan secara sederhana dan disajikan dalam bentuk tabel dan grafik, sehingga mudah dipahami.

3. Menarik Kesimpulan

Penarikan kesimpulan dilakukan dalam bentuk pernyataan yang dimaksudkan untuk menjawab rumusan masalah.

\section{Kriteria Keberhasilan Tindakan}

Kriteria keberhasilan tindakan adalah apabila setelah penerapan Metode Pembelajaran Kooperatif dengan bantuan Tutor Sebaya terjadi peningkatan Motivasi Belajar Akuntansi, dalam hal ini pada kompetensi dasar membuat jurnal penyesuaian secara klasikal atau kelas. Indikator keberhasilan tindakan adalah apabila terjadi peningkatan motivasi siswa dalam pembelajaran akuntansi, yang dihitung dengan mempersentasekan skor motivasi siswa pada aspek yang diamati. Dilihat dari segi proses, pembelajaran dikatakan berhasil dan berkualitas jika seluruhnya atau minimal (75\%) siswa terlibat aktif dan menunjukkan kegairahan belajar yang tinggi, semangat belajar yang besar dan rasa percaya diri yang tinggi (Mulyasa, 2008: 101). Tindakan ini dinyatakan berhasil apabila skor rata-rata Motivasi Belajar Akuntansi siswa khususnya pada Kompetensi Dasar Membuat Jurnal Penyesuaian mencapai $75 \%$ atau lebih. 


\section{HASIL PENELITIAN DAN PEMBAHASAN}

Hasil penelitian diperoleh baik dari siklus I maupun siklus II. Hasil penelitian siklus I berdasarkan observasi diketahui bahwa masih ada 3 indikator yang belum mencapai kriteria minimal yang ditentukan yaitu $75 \%$ dan hanya 12 siswa dari 32 siswa yang memiliki motivasi belajar. Berdasarkan hasil tersebut, maka pada siklus II perlu dilakukan perbaikan agar motivasi belajar siswa kelas X Akuntansi 1 dapat mencapai kriteria yang telah ditentukan. Salah satu cara untuk mengatasi masalah tersebut adalah dengan melakukan perubahan kelompok siswa, membimbing tutor lebih lama, mengawasai jalannya diskusi, menegur siswa yang tidak memperhatikan saat presentasi dan mengingatkan siswa untuk tidak mencontek satu sama lain ketika mengerjakan soal tes. Terbukti bahwa terjadi peningkatan motivasi belajar sebesar $11,28 \%$ dari siklus I ke siklus II atau sebesar $74,03 \%$ pada siklus I menjadi $85,31 \%$ pada siklus II dan semua indikator telah mencapai kriteria keberhasilan tindakan. Untuk lebih jelasnya, berikut ini disajikan data perbandingan skor Motivasi Belajar siswa kelas X Akuntansi 1 siklus I dan siklus II berdasarkan data observasi yang terdapat dalam lembar observasi:

Tabel 1. Perbandingan Skor Motivasi Belajar Berdasarkan Observasi pada Siklus I dan Siklus II

\begin{tabular}{|l|c|c|c|}
\hline \multirow{2}{*}{ Indikator } & \multicolumn{2}{c|}{ Persentase } & $\begin{array}{c}\text { Pening- } \\
\text { katan (\%) }\end{array}$ \\
\cline { 2 - 4 } & Siklus I (\%) & Siklus II (\%) & I-II \\
\hline Tekun menghadapi tugas & 79,31 & 85,00 & 5,69 \\
\hline Ulet menghadapi kesulitan & 84,48 & 98,33 & 13,85 \\
\hline Memiliki minat terhadap pelajaran & 75,00 & 90,00 & 15,00 \\
\hline Senang belajar mandiri & 62,07 & 76,67 & 14,60 \\
\hline Cepat bosan pada tugas-tugas rutin & 75,86 & 92,50 & 16,64 \\
\hline Dapat mempertahankan pendapatnya & 68,97 & 78,33 & 9,37 \\
\hline $\begin{array}{l}\text { Tidak mudah melepaskan hal yang } \\
\text { diyakini }\end{array}$ & 70,69 & 80,00 & 9,31 \\
\hline $\begin{array}{l}\text { Senang mencari dan memecahkan } \\
\text { masalah soal-soal }\end{array}$ & 75,86 & 81,67 & 5,80 \\
\hline Skor rata-rata & $\mathbf{7 4 , 0 3}$ & $\mathbf{8 5 , 3 1}$ & $\mathbf{1 1 , 2 8}$ \\
\hline
\end{tabular}

Perbandingan skor Motivasi Belajar Akuntansi siswa dari siklus I ke siklus II berdasarkan observasi yang dilakukan dapat disajikan pada grafik berikut ini: 
Jurnal Pendidikan Akuntansi Indonesia, Vol. XI, No. 2, Tahun 2013 Evita Rahayu \& Sukanti

$76-90$

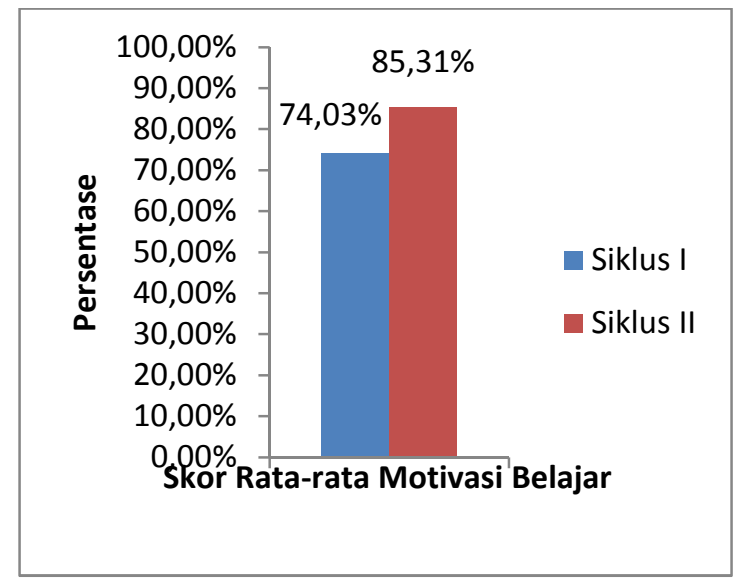

\section{Gambar 1. Grafik Perbandingan Skor Motivasi Belajar Berdasarkan Observasi}

Sedangkan berdasarkan data angket yang didistribusikan kepada siswa pada akhir setiap siklus diperoleh hasil peningkatan motivasi belajar siswa dari siklus I ke siklus II. Berikut ini tabel perbandingan data angket dari siklus I ke siklus II: Tabel 2. Perbandingan Data Angket Motivasi Belajar Siklus I dan Siklus II

\begin{tabular}{|l|c|c|c|}
\hline \multirow{2}{*}{\multicolumn{1}{|c|}{ Indikator }} & \multicolumn{2}{c|}{ Persentase } & $\begin{array}{c}\text { Pening- } \\
\text { katan (\%) }\end{array}$ \\
\cline { 2 - 4 } & Siklus I (\%) & Siklus II (\%) & I-II \\
\hline Tekun menghadapi tugas & 74,54 & 75,89 & 1,35 \\
\hline Ulet menghadapi kesulitan & 70,63 & 80,06 & 9,43 \\
\hline Memiliki minat terhadap pelajaran & 73,76 & 75,89 & 2,13 \\
\hline Senang belajar mandiri & 58,03 & 66,07 & 8,04 \\
\hline Cepat bosan pada tugas-tugas rutin & 75,62 & 77,68 & 2,06 \\
\hline Dapat mempertahankan pendapatnya & 72,22 & 75,29 & 3,07 \\
\hline Tidak mudah melepaskan hal yang diyakini & 70,37 & 73,21 & 2,84 \\
\hline Senang mencari dan memecahkan masalah & 76,85 & 80,65 & 3,80 \\
\hline soal-soal & & & \\
\hline Skor rata-rata & $\mathbf{7 1 , 5 1}$ & $\mathbf{7 5 , 6 0}$ & $\mathbf{4 , 0 9}$ \\
\hline
\end{tabular}

Berdasarkan tabel di atas, perbandingan hasil data angket siklus I dan siklus II disajikan pada grafik berikut ini: 


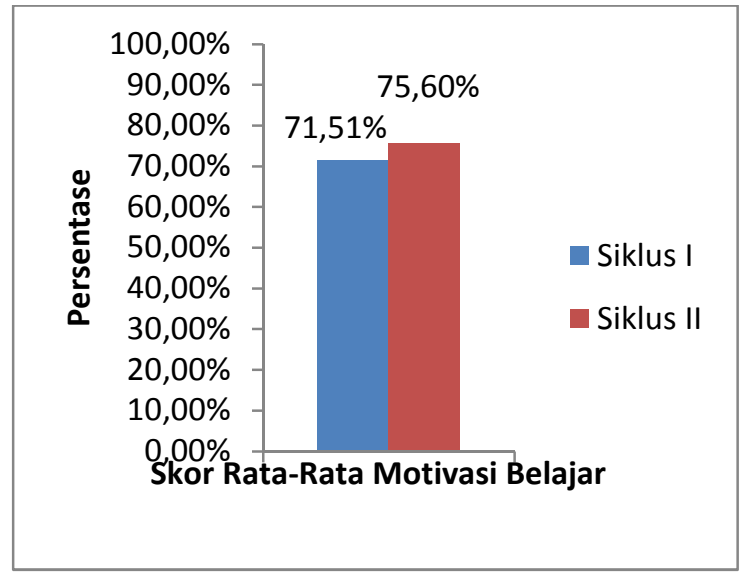

\section{Gambar 2. Grafik Perbandingan Data Angket Motivasi Belajar Siklus I dan Siklus II}

Berdasarkan hasil angket dapat diketahui bahwa skor rata-rata Motivasi Belajar Akuntansi naik dari siklus I sebesar 71,51\% menjadi 75,60\% di siklus II atau terjadi peningkatan sebesar 4,09\%. Demikian juga dengan semua indikator Motivasi Belajar Akuntansi pada angket terjadi peningkatan.

\section{SIMPULAN DAN SARAN}

\section{Simpulan}

Berdasarkan hasil penelitian dan pembahasan pada bab IV dapat disimpulkan bahwa Penerapan Metode Pembelajaran Kooperatif dengan Bantuan Tutor Sebaya dapat meningkatkan Motivasi Belajar pada Kompetensi Dasar Membuat Jurnal Penyesuaian siswa kelas X Akuntansi 1 SMK Negeri 7 Yogyakarta tahun ajaran 2013/2014 yang dibuktikan dengan adanya peningkatan persentase skor rata-rata Motivasi Belajar siswa yang diambil melalui observasi dengan lembar observasi dan data angket.

Berdasarkan hasil observasi, terjadi peningkatan skor Motivasi Belajar siswa pada Kompetensi Dasar Membuat Jurnal Penyesuaian sebelum penerapan Pembelajaran Kooperatif dengan Bantuan Tutor Sebaya sebesar 33,20\% kemudian meningkat menjadi $74,03 \%$ pada siklus I atau terjadi peningkatan sebesar $40,83 \%$. Selanjutnya pada siklus I ke siklus II juga terjadi peningkatan sebesar $11,28 \%$ atau diperoleh skor sebesar 74,03\% pada siklus menjadi $85,31 \%$ pada siklus II.

Berdasarkan angket yang didistribusikan kepada siswa dapat disimpulkan pula bahwa terjadi peningkatan skor Motivasi Belajar siwa pada Kompetensi Dasar Membuat Jurnal Penyesuaian sebesar 4,09\% dimana skor pada siklus I sebesar $71,51 \%$ meningkat menjadi $75,60 \%$ pada siklus II. 


\section{Saran}

\section{a. Bagi Guru}

a. Guru dapat mencoba untuk menerapkan Metode Pembelajaran Kooperatif dengan Bantuan Tutor Sebaya pada kompetensi dasar yang lain yang diharapkan dapat memicu peningkatan minat siswa terhadap kegiatan pembelajaran dan memfasilitasi kesulitan yang dihadapi siswa sehingga keuletan siswa meningkat dan tidak putus asa ketika mengalami kesulitan.

b. Guru perlu untuk merancang pembelajaran yang mampu menumbuhkan kebutuhan siswa untuk belajar. Dengan adanya kebutuhan dalam diri siswa akan memicu tanggungjawab dan kemandirian siswa dalam menyelesaikan tugas individu, sekaligus menciptakan suasana kelas yang tidak monoton sehingga siswa menikmati proses pembelajaran.

c. Dalam melaksanakan pembelajaran, guru dapat menggunakan Metode Pembelajaran Kooperatif dengan Bantuan Tutor Sebaya pada khususnya, untuk menumbuhkan keberanian siswa dalam mengungkapkan pendapat dan argumennya dengan mantab.

\section{b. Bagi Siswa}

a. Siswa sebaiknya memiliki dan menumbuhkan motivasi belajar mereka. Dengan adanya motivasi tersebut diharapkan siswa dapat mencapai tujuan belajarnya.

b. Siswa perlu meningkatkan kemandirian belajarnya sendiri dan tidak menggantungkan jawaban kepada teman.

c. Siswa perlu untuk membiasakan mengutarakan gagasannya dalam pembelajaran. Dengan ini diharapkan dapat memicu kepercayaan diri siswa kemudian memberikan dampak kepada adanya pemahaman siswa akan materi dan siswa akan memiliki argumen yang tepat atas jawabannya, sehingga siswa mampu mempertahankan pendapatnya.

\section{c. Bagi Peneliti Selanjutnya}

a. Sebaiknya ketika melaksanakan pembelajaran kooperatif dengan bantuan tutor sebaya memilih materi yang tidak terlampau sulit, sehingga tutor lebih mudah menerima dan menjelaskan materi kepada anggotanya.

b. Untuk penelitian yang akan datang diharapkan dapat menggambarkan skor Motivasi Belajar siswa secara individual.

\section{E. DAFTAR PUSTAKA}

Agus Suprijono. (2012). Cooperative Learning Teori \& Aplikasi PAIKEM. Yogyakarta: Pustaka Pelajar.

Muhibbin Syah. (2010). Psikologi Belajar. Jakarta: PT Raja Grafindo Persada.. 
Jurnal Pendidikan Akuntansi Indonesia, Vol. XI, No. 2, Tahun 2013

Evita Rahayu \& Sukanti

$76-90$

Mulyasa. (2008). Kurikulum Berbasis Kompetensi. Bandung: PT. Remaja Rosdakarya.

Nana Sudjana. (2012). Penilaian Hasil Proses Belajar Mengajar. Bandung: PT Remaja Rosdakarya

Oemar Hamalik. (2003). Perencanaan Pengajaran Berdasarkan Pendekatan Sistem. Jakarta: Bumi Aksara.

Sardiman AM. (2011). Interaksi dan Motivasi Belajar Mengajar. Jakarta: PT. Rajagrafindo Persada

Sugiyono.(2009). Metode Penelitian Pendidikan. Bandung: Alfabeta.

Suharsimi Arikunto. (2010). Prosedur Penelitian: Suatu Pendekatan Praktek. Jakarta: Rineka Cipta.

. (2012). Penelitian Tindakan Kelas. Jakarta: PT Bumi Aksara.

Wina Sanjaya. (2011). Strategi Pembelajaran Berorientasi Standar Proses Pendidikan. Jakarta: Kencana. 